\title{
Srovnání výkonnosti studentek studijních oborů Tělesná výchova a sport a Fyzioterapie v motorických testech
}

\section{Performance comparison of students of Physical education and sport and students of Physiotherapy in motor tests}

\author{
Zdeněk Havel, Kateřina Vaníková
}

Fakulta zdravotnických studií, Univerzita J. E. Purkyně v Ústí nad Labem

\begin{abstract}
Abstrakt:
Cílem studie je přispět k rozšírení poznatků o úrovni výkonnosti a zdravotně orientované zdatnosti studentek oboru Fyzioterapie, reprezentované studentkami tohoto oboru na Fakultě zdravotnických studii UJEP v Ústí n. L. Výsledné hodnoty porovnáváme s hodnotami dosaženými obecnou populací a studentkami oboru Tělesná výchova a sport. Studentky absolvovaly tyto testy: progresivní člunkový běh na 20 metrů, hod plným míčem obouruč $2 \mathrm{~kg}$ těžkým, skok daleký z mista odrazem snožmo, výdrž ve shybu na hrazdě - držení podhmatem, leh-sed opakovaně po dobu jedné minuty, hluboký předklon v sedu, Iowa Brace test. Dále jsme vypočitali BMI.

Ve své studii jsme si položili dvě otázky. První, jaká je úroveň motorických schopností studentek Fyzioterapie tedy studentek VŠ ve srovnání s obecnou populací, a druhou, jaký je rozdíl v úrovni motorických schopností mezi studentkami studijního oboru Fyzioterapie a oboru Télesná výchova a sport.

Z výsledků vyplynulo, že studentky oboru Fyzioterapie měly shodnou úroveñ motorických schopností jako obecná populace. Se studentkami oboru Tělesná výchova a sport měly shodnou úroveň pouze ve dvou testech, a to v hlubokém predklonu v sedu-flexibilitě a ve výdrži ve shybu na hrazdě.
\end{abstract}

\section{Abstract}

The aim of this study is to contribute expansion of knowledge about the level of the performance and health oriented fitness at represented students of Physiotherapy on Faculty of Health Studies Jan Evangelista Purkynè University in Usti nad Labem. We compare resulting values with the values that were obtained by general population and students of Physical education and sports. Students participated these tests: progressive run for 20 meters, $2 \mathrm{~kg}$ heavy ball throw with both hands, standing long jump with both legs together, flexed-arm hang forward grip for woman, sit-up test 1 minute, deep bend in sitting position, Iowa Brace and calculated Body mass index (BMI).

We asked two questions for our study. First, what is the level of motor skills students of Physiotherapy so academic students, what is the difference of level of motor skills between students of Physiotherapy compared with general population and second, what is the difference of the level of motor skills between students of Physiotherapy and students of Physical education and sports.

Results showed that students of Physiotherapy had the same level of motor skills such as general population. Students of Physiotherapy had the same level in only two tests - deep bend in sitting position - flexibility and flexed-arm hang forward grip for woman with students of Physical education and sports.

Klíčová slova: fyzioterapie, měrení a testování, tělesná výchova sport, tělesná výkonnost

Key words: physiotherapy, measuring and testing, physical education and sport and physical performance 


\section{ÚVOD}

Odborníci pro výkon povolání fyzioterapeuta se v současné době připravují na lékařských fakultách, na fakultách zdravotnických, ale také na třech fakultách sportovních. Při zahájení studia tohoto studijního oboru procházeli uchazeči o studium talentovými zkouškami z tělesné výchovy, v posledních letech tomu tak není a uchazeči o studium jsou přijímáni jen na základě teoretických zkoušek. Vzhledem k jejich budoucímu zaměstnání, které vyžaduje určitou tělesnou výkonnost, nás zajímala úroveň tělesné výkonnosti respektive zdatnosti studentů prvního roku studia tohoto oboru.

V našem př́spěvku srovnáváme úroveň výkonnosti v motorických testech studentek studijního programu Specializace ve zdravotnictví, studijního oboru Fyzioterapie se studentkami studijního programu Tělesná výchova a sport (dále TVS), studijního oboru Tělesná výchova a sport. Dále srovnáváme výkonnost studentek studijního oboru Fyzioterapie s obecnou populací.

Jsme přesvědčeni, že u studijního oboru TVS jde o specifickou skupinu studentek, kde se kromě zdravotně orientované tělesné zdatnosti uplatňuje i výkonově orientovaná tělesná zdatnost. Naproti tomu studentky Fyzioterapie představují populaci studentek vysoké školy (dále VŠ), u nichž bude preferována především zdravotně orientovaná tělesná zdatnost. Ta je nezbytná pro výkon fyzicky náročné profese fyzioterapeuta. Z vyhlášky MZČR č. 55 o činnostech zdravotnických pracovníků a jiných odborných pracovníků (MZ ČR, 2011) vyplývá, že fyzioterapeut aplikuje podle aktuálního stavu pacientů fyzioterapeutické a kinezioterapeutické metody, např́íklad manuální a př́strojové, provádí interpretaci a korekci funkčních poruch pohybového systému, zejména poruch postury, lokomoce a hybnosti. Profese fyzioterapeuta vyžaduje v souvislosti s charakterem většiny její pracovní zátěže vysokou kvalitu svalové koordinace a dodržování základních ergonomických pravidel.

Pokud chceme charakterizovat motorický výkon, výkonnost nebo zdatnost, musíme objasnit jejich funkci. Dostáváme se tak k pohybovým předpokladům, kde základní úlohu mají motorické (pohybové) schopnosti vedle dovedností, somatických ukazatelů aj. Motorickým schopnostem byla a je věnována značná pozornost, nebot' podmiňují pohybovou činnost i v mnoha dalších oborech. Čelikovský (1990) rozumí motorickou schopností „integraci vnitřních vlastností organismu, která podmiňuje splnění určité skupiny pohybových úkolů a současně je jimi podmíněna“. „Burton \& Miller (1998) uvádí: „Motorické schopnosti jsou obecné rysy (vlastnosti) či kapacity, které podkládají výkonnost v řadě pohybových dovedností““ (Měkota, 2005). Právě tato charakteristika odpovídá činnostem fyzioterapeuta.

Zaměřili jsem se na motorické schopnosti. Byli jsme si vědomi, že motorické schopnosti nejsou př́mo měřitelné (Měkota \& Novosad, 2005) a že na jejich úroveň usuzujeme pomocí indikátorů, což byly v tomto případě motorické testy. Vybrali jsme proto testy, ze kterých bylo možné usuzovat kromě motorických schopností i na zdravotně orientovanou tělesnou zdatnost.

Pro naše sdělení jsme si položili dvě otázky. První, jaká je úroveň motorických schopností studentek Fyzioterapie, tedy studentek VŠ, ve srovnání s obecnou populací, a druhou, jaký je rozdíl v úrovni motorických schopností mezi studentkami studijního oboru Fyzioterapie a oboru TVS.

Cílem studie je přispět k rozšiřrení poznatků o úrovni výkonnosti a zdravotně orientované zdatnosti studentek oboru Fyzioterapie, reprezentované studentkami tohoto oboru na Fakultě zdravotnických studií UJEP v Ústí n. L.

\section{HYPOTÉZY STUDIE:}

1. Studentky prvního ročníku studijního oboru Fyzioterapie budou mít shodnou úroveň výkonnosti v motorických testech jako studentky studijního oboru TVS.

2. Úroveň výkonnosti v motorických testech studentek Fyzioterapie ve srovnání s obecnou populací bude vyšší.

Úroveň výkonnosti v motorických testech a z ní odvozená tělesná zdatnost, v tomto př́ípadě zdravotně orientovaná zdatnost, je základem pro zdraví každého jedince i pro celý životní styl člověka (Bunc, 1998). Tento poznatek zvlášt' platí pro studenty obou studijních programů. Důležitým úkolem bylo stanovit testy, popríípadě testovou baterii, ze které můžeme usuzovat na zdravotně orientovanou zdatnost. Ve druhém př́ípadě pak vybrat takové testy, jejichž výsledky byly již dříve použity a mohou sloužit pro srovnání. 


\section{METODIKA PRÁCE}

Výše uvedené faktory jsme vzali v úvahu a vybrali tyto testové položky:

1. Strukturální faktory - somatická měření: tělesná výška, tělesná hmotnost a z toho vypočítaný BMI;

2. kardiovaskulární zdatnost: progresivní člunkový běh na 20 metrů;

3. aerobní zdatnost - Katch-McArdle Step Test (Pollock \& Wilmore, 1990) - hodnocení dle hodnoty maximální spotřeby kyslíku ( $\left.\mathrm{VO}_{2} \max \right)$;

4. svalová zdatnost: hod obouruč plným míčem 2 kg těžkým, skok daleký z místa odrazem snožmo, výdrž ve shybu na hrazdě, držení podhmatem, leh-sed opakovaně po dobu jedné minuty;

5. $\quad$ flexibilita - kloubní pohyblivost: hluboký předklon v sedu;

6. koordinační schopnosti: Iowa Brace test (dále jen IBT). Testová baterie IBT obsahuje koordinačně náročné pohyby, rovnovážná a koordinační tělesná cvičení, položku 1 a 9 je možno pokládat i za test flexibility. Čepička (1999) stanovil obtížnost jednotlivých testových položek a změnou pořadí ovlivnil motivační činitele testovaných osob, čímž zvýšil výpovědní hodnotu testové baterie. Baterií lze testovat nejen koordinační schopnosti, ale určitým způsobem ji můžeme pokládat i za test docility (Štěpnička, 1976).

Všechny ostatní testy byly převzaty z literatury. Základem byl Unifittest (6-60) Měkota \& Kovář et al. (1996), měření i testování probíhalo podle manuálu uvedeného v této literatuře. Výjimku činil Katch-McArdle Step Test, z kterého usuzujeme na aerobní zdatnost, a proto uvádíme jak jeho popis, tak i jeho hodnocení (tab. 1). Druhou výjimkou byl test hod plným míčem obouruč 2 kg těžkým, který je popsán včetně norem u Komeštíka (2006).

Popis testu Katch-McArdle Step Test, aerobní zdatnost - hodnocení dle hodnoty maximální spotřeby kyslíku $\left(\mathrm{VO}_{2} \max \right)$ :

1. Výstupy se provádí na švédskou tělocvičnou lavičku, výška $30 \mathrm{~cm}$.

2. Výstupová frekvence je 24 (muži) nebo 22 (ženy) výstupů za minutu. Je možno využít metronomu nastaveného na 96 (muži), resp. 88 (ženy).

3. Doba vystupovaní je 3 minuty.

4. Po skončení testu testovaná osoba usedne na lavičku.

5. Pět vteřin po ukončení testu měříme palpačně srdeční frekvenci (SF) po dobu 15 vteřin.

6. Zaznamenáme data.

Výpočet hodnoty $\mathrm{VO2}_{\text {max }}$ :

Muži: VO2 ${ }_{\max }=111.33-\left(0.42 \times 15^{\prime} \mathrm{SF} \times 4\right)$

Ženy: $\mathrm{VO} 2{ }_{\max }^{\max }=65.81-\left(0.1847 \times 15^{\circ} \mathrm{SF} x 4\right)$

Tabulka 1: Klasifikace aerobní kapacity pro ženy 20-29 r.

\begin{tabular}{|l|c|c|c|c|c|}
\hline Úroveň & Nízká & Podprůměrná & Průměrná & Nadprůměrná & Vysoká \\
\hline Ženy & $<29$ & $29-34$ & $35-40$ & $41-46$ & $>46$ \\
\hline
\end{tabular}

(POLLOCK \& WILMORE, 1990)

\section{CHARAKTERISTIKA SOUBORU}

Výzkumný soubor tvořilo 25 studentek prvního ročníku studijního oboru TVS a 39 studentek studijního oboru Fyzioterapie. Studentky tohoto oboru prošly přijímacím řízením na základě teoretických testů z biologie člověka a somatologie. Byly vybrány z celkového počtu 359 uchazečů ze středních škol. Studentky jsou z $40 \%$ z gymnázií, $10 \%$ ze středních zdravotních škol, $35 \%$ ze zdravotních lyceí, $10 \%$ z obchodních akademií a $5 \%$ $\mathrm{z}$ ostatních středních škol. Věk je uváděn $\mathrm{k}$ datu měření s přesností jednoho měsíce (tab. 2). Měření a testování probíhalo v únoru a březnu roku 2013 ve sportovní hale PF UJEP. 
Tabulka 2.: Průměrný věk a počet studentek.

\begin{tabular}{|l|c|c|}
\hline \multirow{2}{*}{ TVS } & $\overline{\mathbf{x}}$ & 20,1 \\
\cline { 2 - 3 } & $\mathrm{n}$ & 25 \\
\hline \multirow{3}{*}{ Fyzioterapie } & $\overline{\mathbf{x}}$ & 19,9 \\
\cline { 2 - 3 } & $\mathrm{n}$ & 39 \\
\hline
\end{tabular}

\section{STATISTICKÉ ZPRACOVÁNÍ}

Pro statistické vyhodnocení dat jsme použili program Statistica a provedli následující statistické výpočty: základní statistické charakteristiky polohy a variability (aritmetický průměr, směrodatná odchylka, Me, Mo, $\mathrm{R}$ - variační rozpětí), t-test pro nezávislé výběry, Mann Whitney U-test, $\chi^{2}$-test, pro věcnou významnost pak $\mathrm{d}, \omega^{2}, \eta^{2}$.

\section{VÝSLEDKY}

Výsledné hodnoty a hodnoty Iowa Brace testu jsou uvedeny v tabulkách 3-8. Průměrné hodnoty BMI a motorických testů žen obou souborů jsou porovnány t-testem pro nezávislé výběry (tab. 5). Hodnoty Iowa Brace testu jsou porovnány Mann Whitney U-testem a $\chi^{2}$-testem (tab. 5 a 6). Interkorelace znaků a testů studentek obou souborů jsou uvedeny v tabulkách 7 a 8.

\section{Složení těla}

Ze somatických ukazatelů byla zjišt'ována tělesná výška a tělesná hmotnost pro výpočet BMI. Odvozená hodnota indexu BMI (tab. 3 a 4) nás informuje, zda aktuální tělesná hmotnost odpovídá tělesné výšce, nebo zda je nadměrná či snížená. Přestože hodnoty ve všech statistických charakteristikách se u obou souborů liší, nejde o statistickou významnost. Ukázalo se, že studentky oboru TVS mají vyšší průměr, medián i modus.

\section{Motorické testy}

Ve všech měřených testech má soubor TVS vyšší průměry a mediány kromě průměru flexibility (tab. 3 a 4). Statistická významnost (tab. 5) ve prospěch TVS je signifikantní na hladině 0,01 u testů: progresivní člunkový běh na 20 metrů, aerobní zdatnost - Katch-McArdle Step Test, hod obouruč plným míčem 2 kg těžkým, skok daleký z místa odrazem snožmo, sed-leh opakovaně po dobu jedné minuty. O statisticky významný rozdíl nejde mezi soubory v testu výdrž ve shybu na hrazdě a testu flexibility. Zatímco u výdrže ve shybu je průměr a medián vyšší a nejde o statistickou významnost, u flexibility jsou všechny hodnoty téměř shodné.

Srovnáme-li průměrné hodnoty jednotlivých testů studentek Fyzioterapie s normami pro obecnou populaci uvedenými v literatuře Unifittest (6-60) Měkota \& Kovář et al. (1996, tab. 9), zjišt’ujeme, že se u tohoto souboru jedná o poměrně nižší výkonnost. Podprůměrných hodnot dosáhly tyto studentky v progresivním člunkovém běhu na 20 metrů, v testu skok daleký z místa odrazem snožmo a v lehu-sedu opakovaně po dobu jedné minuty. Pouze v testu výdrž ve shybu na hrazdě byly ve své věkové kategorii nadprůměrné. Rovněž nadprůměrné byly v aerobní zdatnosti - Katch-McArdle Step Testu podle norem Pollocka \& Wilmora, 1990 (tab. 1). Podle norem Komeštíka (2006) je výsledný průměr v hodu plným míčem obouruč 2 kg těžkým a v hlubokém předklonu $\mathrm{v}$ sedu v průměru jejich věkové kategorie.

Iowa Brace test

$\mathrm{V}$ tab. 3 a 4 jsou výsledné hodnoty Iowa Brace testu $\mathbf{v}$ rámci hodnocené baterie, medián, modus a variační rozpětí. U souboru TVS je poměrně vysoký medián i modus, ale menší variační rozpětí. Hodnoty Iowa Brace testu jsou porovnány Mann Whitney U testem (tab. 5), zjistili jsme statistickou významnost 
mezi soubory ve prospěch souboru TVS na hladině významnosti $\alpha_{0,01}$ Jde sice o věcnou významnost se středním efektem, ale významným \% (63,00). Z norem Komeštíka (2006) a výpočtu $\chi^{2}$-testu můžeme opět potvrdit vyšší výkonnost studentek TVS na hladině významnosti $\chi_{0,01}^{2}$ (tab. 6).

Interkorelace testů a znaků

Výpočtem interkorelací testů a znaků jsme chtěli zjistit, jaké jsou vzájemné vztahy mezi znaky a skupinami motorických schopností a zda jsou vzájemné závislosti shodné u tak rozdílných (specifických) souborů. Pro soubor TVS jsme vzhledem k trénovanosti a praktické výuce založené opět víceméně na sportovním tréninku předpokládali určité závislosti. V tab. 7 a 8 jsou uvedeny statistické významnosti. U obou souborů koreluje negativně BMI s výdrží ve shybu na hrazdě, IBT pozitivně s výdrží ve shybu na hrazdě a rovněž pozitivně korelují oba testy explozivně silové, hod plným míčem obouruč 2 kg těžkým a skok daleký z místa odrazem snožmo mezi sebou, i když s různou hladinou významnosti. Více společných korelací jsme u souborů nenašli. U souboru TVS vyšla očekávaná závislost mezi kardiovaskulární zdatností (progresivním člunkovým během na 20 metrů) a aerobní zdatností ( $\left.\mathrm{VO}_{2} \max \right)$, u oboru Fyzioterapie byla vypočítaná hodnota poměrně nízká, statisticky nevýznamná. U oboru Fyzioterapie však vyšel statisticky vyšší počet korelací (8), a to na hladině významnosti $\mathrm{r}_{0,01}$.

\section{DISKUSE}

U studentek studijního programu TVS se předpokládá dobrá až výborná úroveň motorických schopností. Jak je uvedeno v úvodu, srovnáváme úroveň výkonnosti v motorických testech (zdravotně orientovanou zdatnost) studentek studijního oboru Fyzioterapie se studentkami studijního oboru TVS a jednak studentek studijního oboru Fyzioterapie s obecnou populací.

Jsme přsesvědčeni, že u studijního oboru TVS jde o specifickou skupinu studentek, kde se uplatňuje i výkonově orientovaná tělesná zdatnost, naproti tomu u studentek Fyzioterapie bude preferována především zdravotně orientovaná tělesná zdatnost. Jejich budoucí profese ale vyžaduje v souvislosti s charakterem pracovní zátěže vysokou kvalitu svalové koordinace a určitou úroveň zdatnosti i výkonnosti.

\section{BMI}

Vypočítaný průměrný index BMI patří podle norem Riegrové \& Ulbrichové (1993) u obou souborů do skupiny „normální hodnota“ (tab. 3 a 4). Podíváme-li se však na jednotlivé probandky v souborech, zjišt'ujeme, že u studentek TVS měly pouze tři podváhu a tři nadváhu. U souboru Fyzioterapie mělo podváhu 16 studentek a pouze dvě nadváhu. Můžeme konstatovat, že složení těla studentek z obou souborů je v souladu s populačním průměrem a výsledné hodnoty nás vedou k přesvědčení, že studentky vysoké školy kontrolují svoji hmotnost. Vyšší hodnoty souboru TVS přisuzujeme objemu svalové hmoty, což tyto normy neberou v úvahu.

\section{Motorické testy}

Výsledky nepotvrdily naší 1. hypotézu, že studentky prvního ročníku studijního oboru Fyzioterapie budou mít shodnou úroveň výkonnosti v motorických testech jako studentky studijního oboru TVS. Studentky Fyzioterapie měly shodné výsledky se studentkami TVS pouze ve dvou testech, a to v hlubokém předklonu v sedu - flexibilitě a ve výdrži ve shybu na hrazdě (tab. 5). U flexibility hrají významnou roli genetické předpoklady. Výdrž ve shybu nás překvapila vhledem k explozivním silovým testům, ve kterých dosáhly studentky Fyzioterapie poměrně nízké hodnoty.

Hodnoty vytrvalostních testů u studentek Fyzioterapie byly skutečně na nízké úrovni vzhledem k studentkám TVS, což dokládají procenta věcné významnosti (tab. 5). Na základě zkušenosti s testem progresivní člunkový běh na 20 metrů jsme se snažili studentky maximálně motivovat, ale výsledky ukázaly, že vytrvalost i u studentek VŠ závisí především na volních vlastnostech, které v oblasti tělesné aktivity studentkám chyběly. Podobně tomu bylo i v dalším testu leh-sed, kde je určitým faktorem vytrvalostní složka.

Z vypočítaných korelací vyšla očekávaná závislost mezi kardiovaskulární zdatností (progresivním člunkovým během na 20 metrů) a aerobní zdatností ( $\mathrm{VO}_{2}$ max) jen u souboru TVS (tab. 7), u oboru Fyzioterapie byla vypočítaná hodnota poměrně nízká, statisticky nevýznamná (tab. 8). Potvrzuje to nechut' studentek 
Fyzioterapie k vytrvalostním činnostem, i když jejich organismus by větší zátěž zvládl. Pozitivní korelace obou testů explozivně silové schopnosti, hod plným míčem a skok daleký z místa mezi sebou, i když s různou hladinou významnosti, dokazuje shodu explozivní síly horních a dolních končetin. Z dalších korelačních koeficientů (tab. 8) u oboru Fyzioterapie lze soudit na celkovou pozitivní nebo negativní výkonnost nebo spíše na provádění či neprovádění pohybových aktivit. Pohyb se aktivně podílí na celé ontogenezi, utváří a usměrňuje vývoj organismu člověka. Racionální zařazování pohybu do denního režimu je nezbytné, stejně jako jeho analýza (Zvonař, M. et al., 2011).

Výsledky nepotvrdily ani naší 2. hypotézu, že úroveň výkonnosti v motorických testech studentek Fyzioterapie ve srovnání s obecnou populací bude vyšší.

Je to proto, že srovnáním průměrných hodnot testů progresivní člunkový běh na 20 metrů, skok daleký z místa odrazem snožmo, leh-sed s normami pro obecnou populaci (Měkota \& Kovář et al., 1996, tab. 9), jsme zjistili, že se jednalo o poměrně nižší výkonnost, nebot' studentky v těchto testech dosáhly podprůměrných hodnot. Nadprůměrné byly ve své věkové kategorii v testu výdrž ve shybu na hrazdě a v aerobní zdatnosti Katch-McArdle Step Testu podle norem Pollocka \& Wilmora, 1990 (tab. 1). Aerobní zdatnost se synonymem kardiorespirační vytrvalost je pilírem zdravotně orientované zdatnosti. Máček \& Radvanský (2011) ji definuje jako schopnost přijímat, transportovat a využívat kyslík. Fyziologickým podkladem je zapojování „pomalých” svalových vláken a uplatnění oxidativního způsobu uspokojování energetických nároků. Vytrvalostní schopnosti mají tak mezi ostatními motorickými schopnostmi nejzřetelněji vymezený vztah ke konceptu lidského zdraví. Jejich úroveň reflektuje funkční kapacitu a připravenost organismu optimálně reagovat na stresové faktory zevního prostředí. Nízká úroveň aerobní (kardiorespirační) zdatnosti je spojována se zvýšeným rizikem výskytu kardiovaskulárních onemocnění, diabetu typu 2 a zvýšenou úmrtností (Jurca, 2005).

Je podivné, že výsledek aerobní zdatnosti neovlivnil další testy s vytrvalostním faktorem, např́klad právě sedy-lehy a progresivní člunkový běh. Je možné věřit, že studentky aerobní vytrvalosti využijí v pozdějším věku. Podle norem Komeštíka (1995) pak byly studentky Fyzioterapie v průměru své věkové kategorie v hodu plným míčem obouruč $2 \mathrm{~kg}$ těžkým a v hlubokém předklonu v sedu.

\section{Iowa Brace test}

Testová baterie Iowa Brace testu obsahuje koordinačně náročné pohyby, rovnovážná a koordinační tělesná cvičení, některé položky je možno pokládat i za test flexibility. V tab. 3 a 4 jsou výsledné hodnoty Iowa Brace testu medián, modus a variační rozpětí, v tab. 6 je pak uvedeno splnění normy Komeštíka (2006) jednotlivými probandy. Měkota \& Novosad (2005) uvádí, že maximální výkonnost v koordinačních schopnostech je v období 20-30 let. Z výsledků vyplývá, že 56 \% studentek Fyzioterapie test nesplnilo, a my můžeme usuzovat na nízký rozvoj koordinačních schopností během školní tělesné výchovy v předcházejícím studiu.

Výsledky testů motorických schopností a z nich vyplývající zdravotně orientovaná tělesná zdatnost změnily náš názor, kdy jsme předpokládali, že tyto studentky budou provádět pohybovou aktivitu a usilovat o určitou zdatnost. Právě období adolescence je pokládáno za vrchol motorické aktivity života člověka, kdy mizí anatomické disproporce a diskoordinace motoriky předchozího období (Zvonař, M. et al., 2011).

Nízký rozvoj koordinačních schopností u studentek studujících zdravotní studijní obor, zvláště když se v řadě odborných předmětů seznamují s důležitostí pohybové aktivity pro zdravý životní styl, je zarážející. Jediným polehčujícím faktorem je, že jsme testovali studentky 1. ročníku studia. Z vypočítaných korelací jsme zjistili závislost testů skoku dalekého z místa, výdrží ve shybu a progresivního člunkového běhu na testové baterii IBT, přičemž pouze ve výdrži ve shybu dosáhly studentky Fyzioterapie lepších výsledků. Negativně se projevila korelace mezi BMI a IBT.

\section{ZÁV̌̌R}

1. Pro své sdělení jsme si položili dvě otázky. První, jaká je úroveň motorických schopností studentek Fyzioterapie tedy studentek VŠ, ve srovnání s obecnou populací, a druhou, jaký je rozdíl v úrovni motorických schopností mezi studentkami studijního oboru Fyzioterapie a oboru TVS. Tomu odpovídaly i hypotézy.

2. Pro odpověd' na tyto otázky jsme nashromáždili hodnoty 25 studentek prvního ročníku studijního oboru TVS a 39 studentek studijního oboru Fyzioterapie na UJEP v Ústí n. L.

3. Studentky jsme změřili v testech: progresivní člunkový běh na 20 metrů, hod plným míčem obouruč 
2 kg těžkým, skok daleký z místa odrazem snožmo, výdrž ve shybu na hrazdě - držení podhmatem, leh-sed opakovaně po dobu jedné minuty, hluboký předklon v sedu, Iowa Brace test. Dále jsme vypočítali BMI.

\section{Z VÝSLEDKŮ VYPLYNULO:}

a) Vypočítaný průměrný index BMI patří podle norem Riegrové \& Ulbrichové (1993) u obou souborů do skupiny „,normální hodnota“. Můžeme konstatovat, že složení těla obou souborů je v souladu s populačním průměrem. Zároveň to potvrzuje, že studentky vysoké školy kontrolují svou hmotnost.

b) Výsledky nepotvrdily naší 1 . hypotézu, že studentky prvního ročníku studijního oboru Fyzioterapie budou mít shodnou úroveň výkonnosti v motorických testech jako studentky studijního oboru TVS. Studentky Fyzioterapie měly shodné výsledky se studentkami TVS pouze ve dvou testech, a to $\mathrm{v}$ hlubokém předklonu v sedu - flexibilitě a ve výdrži ve shybu na hrazdě. U ostatních testů dosáhly studentky Fyzioterapie poměrně nízké hodnoty.

c) Výsledky nepotvrdily ani naší 2. hypotézu, že úroveň výkonnosti v motorických testech studentek Fyzioterapie ve srovnání s obecnou populací bude vyšší. Je to proto, že srovnáním průměrných hodnot testů progresivní člunkový běh na 20 metrů, skok daleký z místa odrazem snožmo, leh-sed s normami pro obecnou populaci (Měkota \& Kovář, et al., 1996) dosáhly podprůměrných hodnot. Dosáhly sice nadprůměrné hodnoty ve výdrži ve shybu na hrazdě a v aerobní zdatnosti podle norem Pollocka \& Wilmora (1990), dle norem Komeštíka (2006) pak byly v průměru své věkové kategorie v hodu plným míčem obouruč $2 \mathrm{~kg}$ těžkým a v hlubokém předklonu $\mathrm{v}$ sedu.

d) Úroveň výkonnosti $\mathrm{v}$ motorických testech a $\mathrm{z}$ toho vyplývající zdravotně orientovaná zdatnost studentek oboru Fyzioterapie studujících zdravotnický studijní obor je překvapující vzhledem k tomu, že se v řadě odborných předmětů seznamují s důležitostí pohybové aktivity pro zdravý životní styl. Z vypočítaných korelačních koeficientů u oboru Fyzioterapie lze vyvodit závěr, že se studentky pravidelným pohybovým aktivitám nevěnují.

\section{LITERATURA:}

Bunc, V. (1998). Zdravotně orientovaná zdatnost a možnosti její kultivace na základní škole. Těl. Vých. Sport. Mlád. č. 4, 2-10.

Čelikovský, S. et al. (1990). Antropomotorika pro studující tělesnou výchovu. (3. přeprac.vyd.) Praha: Státní pedagogické nakladatelství.

Čepička, L. (1999). Stanovení obtížnosti motorického testu. Česká kinantropologie. 3(1). 87-94.

Jurca, R. et al. Assessing Cardiorespiratory Fitness Without Performing Exercise Testing. American Journal of Preventive Medicine, 2005, vol. 29, no. 3. 185-193.

Komeštík, B. (2006). Kinantropologie - Antropomotorika - Metodologie. (1. vyd.) Olomouc: Univerzita Palackého.

Máček, M., \& Radvanský, J. (2011). Fyziologie a klinické aspekty pohybové aktivity. Praha: Galén.

Měkota, K., Kovář, R. et al. (1996). Unifittest (6-60). Manuál pro hodnocení základní motorické výkonnosti a vybraných charakteristik tělesné stavby mládeže a dospělých v České republice. Ostrava: Pedagogická fakulta Ostravské univerzity.

Měkota, K. \& Novosad, J. (2005). Motorické schopnosti. Olomouc: Univerzita Palackého v Olomouci, Fakulta tělesné kultury.

Ministerstvo zdravotnictví České republiky. (2011). Vyhláška č. 55 o činnostech zdravotnických pracovníků a jiných odborných pracovníkủ. Praha: Ministerstvo vnitra

Pollock, M. L. \& Wilmore, J. (1990). Exercise in health and disease: Evaluation and prescription for prevention and rehabilitation. Philadelphia: W. B. Saunders.

Riegrová, J., \& Ulbrichová, M. (1993). Aplikace fyzické antropologie v tělesné výchově a sportu. Olomouc: Univerzita Palackého v Olomouci, PF. 
Štěpnička, J. (1976). Somatotyp, drženi těla, motorika a pohybová aktivita mládeže. Praha: Univerzita Karlova, FTVS.

Zvonař, M., Pavlík, J., Vespalec, T., \& Duvač, I. (2011). Antropomotorika: pro magisterský program tělesná výchova a sport. (1. vyd.) Brno: Masarykova univerzita.

Tabulka 3.: Statistické charakteristiky somatických znaků a testì studentek Fyzioterapie

\begin{tabular}{|l|l|l|l|l|l|}
\hline Testy & $\overline{\mathbf{x}}$ & SD & Me & Mo & R \\
\hline BMI & 21,27 & 2,52 & 20,57 & 19 & 10 \\
\hline Fáze & 4,0 & 1,37 & 4 & 4 & 6 \\
\hline $\mathrm{VO}_{2 \text { max }}$ & 43,8 & 4,1 & 43,6 & 48 & 17 \\
\hline Hod & 608,7 & 86,5 & 600 & 550 & 370 \\
\hline Skok daleký & 170,9 & 23,8 & 170 & 160 & 96 \\
\hline Výdrž ve shybu & 27,7 & 17,1 & 27 & 45 & 60 \\
\hline Sed-leh & 31,3 & 4,2 & 32 & 31 & 21 \\
\hline Flexibilita & 27,3 & 8,1 & 26 & 18 & 29 \\
\hline IBT & - & - & 12 & 12 & 16 \\
\hline
\end{tabular}

Tabulka 4.: Statistické charakteristiky somatických znaků a testů studentek TVS

\begin{tabular}{|l|l|l|l|l|l|}
\hline Testy & $\overline{\mathbf{x}}$ & SD & Me & Mo & R \\
\hline BMI & 22,26 & 2,13 & 22,1 & 23,5 & 7,9 \\
\hline Fáze & 7,3 & 1,7 & 7,5 & 7,5 & 8 \\
\hline $\mathrm{VO}_{2 \max }$ & 50,92 & 7,1 & 49 & 48 & 30 \\
\hline Hod & 786 & 110 & 800 & 620 & 370 \\
\hline Skok daleký & 196,8 & 31,9 & 200 & 200 & 148 \\
\hline Výdrž ve shybu & 33,6 & 15,3 & 41 & 45 & 58 \\
\hline Sed-leh & 46,8 & 7,9 & 46 & 46 & 35 \\
\hline Flexibilita & 27,3 & 6,2 & 28 & 26 & 26 \\
\hline IBT & - & - & 17 & 18 & 7 \\
\hline
\end{tabular}


Tabulka 5.: Srovnání hodnot testi̊ studentek Fyzioterapie a TVS

\begin{tabular}{|l|l|l|}
\hline Testy & $\mathbf{t}-$ test & $\boldsymbol{\omega}^{2}, \mathbf{d}-\mathbf{v} \%$ \\
\hline BMI & 1,687 & - \\
\hline Fáze & $8,492^{* *}$ & 52,63 \\
\hline VO $_{2 \max }$ & $4,577^{* *}$ & 23,76 \\
\hline Hod & $7,201 * *$ & 44,28 \\
\hline Skok daleký & $3,715^{* *}$ & 16,67 \\
\hline Výdrž ve shybu & 1,415 & - \\
\hline Sed-leh & $8,983 * *$ & 55,46 \\
\hline Flexibilita & 0,015 & - \\
\hline IBT & p-level $=0,0000004 * *$ & 63 \\
\hline
\end{tabular}

hladina významnosti $\mathrm{t}-$ testu $\left.*) \mathrm{t}_{0,05}=2,035 * *\right) \mathrm{t}_{0,01}=2,665$

Cohenův koeficient $\mathrm{d}=0,63-$ střední efekt

Tabulka 6.: Hodnocení IOWA BRACE testu studijních oborů podle norem Komeštíka (1995)

\begin{tabular}{|l|l|l|l|l|l|}
\hline Stud. obor & Špatně & Dobře & Výborně & $\chi^{2}$-test & $\eta^{2} \mathbf{v} \%$ \\
\hline Fyzioterapie & 22 & 11 & 6 & 22.643 & 17,69 \\
\hline TVS & 0 & 12 & 13 & & \\
\hline
\end{tabular}

výborně $>16$ bodů, dobře $13-16$ bodů, špatně $<13$ bodů $\quad \chi_{0,01}^{2}=9,21$

(Komeštík, 1995)

Tabulka 7.: Interkorelace znaků a testi̊ studentek TVS

\begin{tabular}{|l|l|l|l|l|l|l|l|l|}
\hline Znak & BMI & Flexibilita & Dálka & Leh-sed & Výdrž & Hod & Fáze & $\mathrm{VO}_{2}$ \\
\hline Flexibilita & 0,005 & & & & & & & \\
\hline Dálka & 0,177 & 0,114 & & & & & & \\
\hline Leh-sed & $-0,057$ & 0,206 & 0,106 & & & & & \\
\hline Výdrž & $-0,402^{*}$ & $-0,098$ & 0,279 & 0,314 & & & & \\
\hline Hod & 0,268 & 0,138 & $0,436^{*}$ & 0,183 & 0,158 & & & \\
\hline Fáze & 0,088 & 0,009 & 0,222 & 0,002 & 0,304 & $0,402^{*}$ & & \\
\hline VO2 & 0,035 & $-0,353$ & $0,516^{* *}$ & 0,099 & $0,501^{*}$ & 0,171 & $0,555^{* *}$ & \\
\hline IBT & 0,026 & $0,0,181$ & 0,078 & 0,154 & $0,458^{*}$ & 0,078 & 0,180 & 0,204 \\
\hline
\end{tabular}

*) $\left.\mathrm{r}_{0,05}=0,396 \quad * *\right) \mathrm{r}_{0,01}=0,505$ 
Tabulka 8.: Interkorelace znaků a testi̊ studentek Fyzioterapie

\begin{tabular}{|l|l|l|l|l|l|l|l|l|}
\hline Znak & BMI & $\begin{array}{l}\text { Flexibi- } \\
\text { lita }\end{array}$ & Dálka & Leh-sed & Výdrž & Hod & Fáze & VO2 \\
\hline Flexibilita & 0,102 & & & & & & & \\
\hline Dálka & 0,313 & 0,258 & & & & & & \\
\hline Leh-sed & 0,036 & 0,043 & 0,113 & & & & & \\
\hline Výdrž & $0,455^{* *}$ & 0,147 & $0,349^{*}$ & 0,054 & & & & \\
\hline Hod & 0,221 & 0,179 & $0,489^{* *}$ & 0,290 & 0,020 & & & \\
\hline Fáze & 0,155 & 0,267 & 0,246 & 0,003 & $0,453^{* *}$ & 0,196 & & \\
\hline VO2 & 0,046 & 0,064 & 0,087 & 0,028 & 0,221 & 0,028 & 0,170 & \\
\hline IBT & $-0,443^{* *}$ & 0,307 & $0,379^{*}$ & 0,060 & $0,611^{* *}$ & 0,128 & $0,337^{*}$ & 0,038 \\
\hline
\end{tabular}

*) $\left.\mathrm{r}_{0,05}=0,316 \quad * *\right) \mathrm{r}_{0,01}=0,408$

Tabulka 9.: Normy Unifittestu (6-60) žen ve věku $18-20$ roků

\begin{tabular}{|l|c|c|c|c|}
\hline Hodnocení & Skok daleký & Leh - sed & $\begin{array}{c}\text { Vytrvalostní } \\
\text { člunkový běh }\end{array}$ & Výdrž ve shybu \\
\hline Výrazně podprůměrný & do -154 & do -26 & do $-3,50$ & 0 \\
\hline Podprůměrný & $155-174$ & $27-33$ & $3,51-5,00$ & $1-5$ \\
\hline Průměrný & $175-194$ & $34-41$ & $5,01-6,75$ & $6-14$ \\
\hline Nadprůměrný & $195-214$ & $42-48$ & $6,76-8,50$ & $15-33$ \\
\hline Výrazně nadprůměrný & 215 a více & 49 a více & 8,51 a více & 34 a více \\
\hline
\end{tabular}

Převzato (Měkota \& Kovář, et al., 1996) 